\title{
The future of the welfare state : reflections on Rogernomics
}

Citation for published version (APA):

Keizer, P. K., \& Muysken, J. (1997). The future of the welfare state : reflections on Rogernomics. METEOR, Maastricht University School of Business and Economics. METEOR Research Memorandum No. 009 https://doi.org/10.26481/umamet.1997009

Document status and date:

Published: 01/01/1997

DOI:

10.26481/umamet.1997009

Document Version:

Publisher's PDF, also known as Version of record

\section{Please check the document version of this publication:}

- A submitted manuscript is the version of the article upon submission and before peer-review. There can be important differences between the submitted version and the official published version of record.

People interested in the research are advised to contact the author for the final version of the publication, or visit the DOI to the publisher's website.

- The final author version and the galley proof are versions of the publication after peer review.

- The final published version features the final layout of the paper including the volume, issue and page numbers.

Link to publication

\footnotetext{
General rights rights.

- You may freely distribute the URL identifying the publication in the public portal. please follow below link for the End User Agreement:

www.umlib.nl/taverne-license

Take down policy

If you believe that this document breaches copyright please contact us at:

repository@maastrichtuniversity.nl

providing details and we will investigate your claim.
}

Copyright and moral rights for the publications made accessible in the public portal are retained by the authors and/or other copyright owners and it is a condition of accessing publications that users recognise and abide by the legal requirements associated with these

- Users may download and print one copy of any publication from the public portal for the purpose of private study or research.

- You may not further distribute the material or use it for any profit-making activity or commercial gain

If the publication is distributed under the terms of Article $25 \mathrm{fa}$ of the Dutch Copyright Act, indicated by the "Taverne" license above, 


\title{
The Future of the Welfare State: Reflections on Rogernomics
}

\author{
Piet Keizer \\ Joan Muysken* \\ Universiteit Maastricht \\ Dept. of Economics \\ P.O. Box 616 \\ 6200 MD MAASTRICHT \\ the Netherlands \\ Tel.: +31433883821 \\ Fax: +31433261555 \\ E-mail: \\ P.Keizer@algec.unimaas.NL \\ J.Muysken@algec.unimaas.NL
}

\begin{abstract}
In this paper we recognize that reforms of the welfare state can be necessary from an economic point of view. We stress, however, that these reforms also have important social and political dimensions. The social dimensions are conceptualised by using Hofstede's cultural characteristics. The scores on each of these characteristics can be related to desired characteristics of the welfare state. In a similar way different political views are related to a desired concept of the welfare state. Since consensus is a necessary condition for a successful reform of the welfare state, the reforms should be consistent with the culture of a society and its dominant political view.

We apply these insights to the reforms in New Zealand, since these are very radical in nature and have attracted a lot of attention. Hofstede's scores are used to measure the culture of New Zealand and the political views are derived from election results. Using these measures, we find that the reforms in New Zealand are inconsistent with the culture and the dominant political views of that country. Therefore we expect that a further implementation of the reforms will run into trouble. In order to provide some background, we describe the economic situation in New Zealand and compare it with that of Australia. Since the economic situation of New Zealand does not outperform that of Australia, the favourable developments in New Zealand are not an obvious consequence of the reforms, as it is sometimes claimed. Moreover, we find that income inequalities have increased sharply in New Zealand and that the lower and middle-class incomes did not increase since 1980.
\end{abstract}

Maastricht, 14th March 1997

* The author thanks NWO for a research grant to visit several universities in Australia. The paper has benefitted from comments on a presentation of an earlier version at the University of Newcastle (NSW, Australia) and many conversations with staffmembers of that university. 


\section{Contents}

1. Introduction

2. New Zealand and Australia compared: smaller is more beautiful?

2.1 The macroeconomic situation

2.2 Employment and unemployment

2.3 Government expenditures and taxes

2.4 The income distribution

2.5 Smaller is more beautiful?

3. Economic performance and the welfare state

3.1 Introduction

3.2 The nature of the welfare state

3.3 Social constraints

3.4 Political constraints

4. Lessons from New Zealand

4.1 The welfare state in New Zealand

4.2 The social situation

4.3 The political situation

5. Concluding remarks 


\section{Introduction}

In most Western European countries a broad agreement exists that reforms of the welfare state are inevitable. And with respect to the nature of these reforms there is a strong tendency towards a more market oriented approach. Some participants in this discussion even adhere to the adage: the more market the better. As an argument to illustrate their case they then point at the recent reforms in New Zealand, sometimes nick-named 'Rogernomics'. ${ }^{1}$ This line of the discussion inspired us to look somewhat closer at the developments in New Zealand on the one hand. But even more important, it motivated us to think more carefully about our strong feeling that there are dangers of overshooting in reforming the welfare state along these lines. Almost inevitably - and often on purpose - these reforms will lead towards larger inequalities in society and less social security. However, this has also consequences for the social fabric which constitutes economic life. And one should be very careful not to destroy much of this fabric without replacing it by new elements, otherwise there can be serious repercussions on economic performance too.

Thus our paper consists of three parts. First we will discuss the recent favourable economic performance of New Zealand. In particular we will look at the claim that the better economic situation should be seen as a result of the reforms. To this end we will compare the economic performance of New Zealand with that of Australia. This is interesting since on the one hand both countries are exposed to similar relevant developments in the world economy. On the other hand, the welfare state in Australia has many characteristics which have been abolished in New Zealand. We shall show that New Zealand certainly is not doing better than Australia.

Second, we will argue that destruction of the social fabric of a society can have serious unintended consequences on economic performance. People living in a structure that they perceive as fair and stable will show a stronger motivation and will invest more in terms of human capital. For our analysis this implies that the nature of the welfare state, and hence also the kind and magnitude of eventual reform policies, do not only depend on the economic situation, but also on the social and the political situation. Although this may seem obvious, it is not always recognized that social and political restrictions should be considered explicitly when analysing the welfare state. We elaborate below how these restrictions should be included in the analysis by characterizing the welfare state according to several cultural dimensions, which can be observed in reality, and political views, which can also be observed.

In the third part of our paper we use New Zealand is a typical example to which we apply our analysis. Observations on the nature of the welfare state and its reforms are confronted with observations on the culture of New Zealand, and its political views. As a consequence we will argue that Rogernomics is not the proper answer - it is inconsistent with the culture of New Zealand and its dominant political views - and other measures should be implemented to restructure the economic situation in New Zealand.

We will conclude our paper with a summary of the main arguments.

1 These reforms have been introduced in New Zealand in order to improve flexibility in the economy and to decrease the burden of the welfare state. One of the main initiators of these reforms was Roger Douglas, who is very active in public debates. 


\section{New Zealand and Australia compared: smaller is more beautiful?}

Australia and New Zealand face similar influences from the world trade and have similar origins stemming from their common British past. Till the early eighties also the economic climate and industrial relations in both countries were quite similar. However, in the early eighties both countries reacted in quite different ways to the deterioration of the economic situation which was exacerbated after the two oil crises. This makes it interesting to compare the economic performance of both countries nowadays. ${ }^{2}$

In 1983 in Australia the Hawke government integrated deregulatory policies with neo-corporatist policies for the labour market and industrial relations, resulting in the Accord between the labour government and the trade unions. In New Zealand, however, in 1984 the Lange government started out with a series of deregulatory strong supply-side oriented policies. ${ }^{3}$

The reforms in New Zealand initially only affected the labour market indirectly through the product market. However, the introduction of the Employment Contracts Act in 1990 also led to a fundamental restructuring of the labour market, with a strong decline of the role of the unions and decentralized wage bargaining.

These reforms have been applauded consistently by The Economist. For instance, with the headline 'smaller is more beautiful', a recent issue of The Economist compared the performance of the New Zealand economy with that of Australia to claim that 'New Zealand is gaining a long term economic edge over Australia' and suggested that this is due to the tougher stand on economic reforms in New Zealand. ${ }^{4}$ Three issues are emphasized to make the point: (1) the rate of unemployment is lower in New Zealand, (2) while the government budget of Australia shows persistent deficits, New Zealand has turned to a budget surplus and (3) GDP growth is strong. In this section we will make a more thorough comparison of the Australian and New Zealand economic performance, and argue that the above mentioned claim can not be substantiated.

\subsection{The macroeconomic situation}

Figure 1 shows the development of real GDP in both countries. One sees that GDP-growth in Australia was much higher in the past and that New Zealand only picked up a similar growth in 1991. However, GDP per capita in New Zealand is still about 15 per cent lower in terms of purchasing power parities. ${ }^{5}$ Consumption growth shows a similar development as GDP growth in both countries.

2 Somewhat similar comparisons are found in Bray and Haworth (1993) and Rasmussen cs. (1995).

3 This contrast is elaborated in Bray and Haworth (1993, pp. 7-8).

$4 \quad$ The Economist, March 25th, 1995, p. 83.

5 Actually New Zealand was a very prosperous country in the early fifties. It was ranked third in 1953, together with Switzerland, in terms of per capita GDP. In 1992 the purchasing power was US\$16,800 in Australia and US\$14,300 in New Zealand, respectively.

Kelsey (1995, pp. 244-245), also referring to Easton, claims that the low rate of growth in the period 1986 - 1993, is due to Rogernomics. This partly caused the decline in the relative position of New Zealand. (The other cause is the low growth in the period 1966 - 1977 due to the falling terms of trade as export prices fell.) 
Figure 1

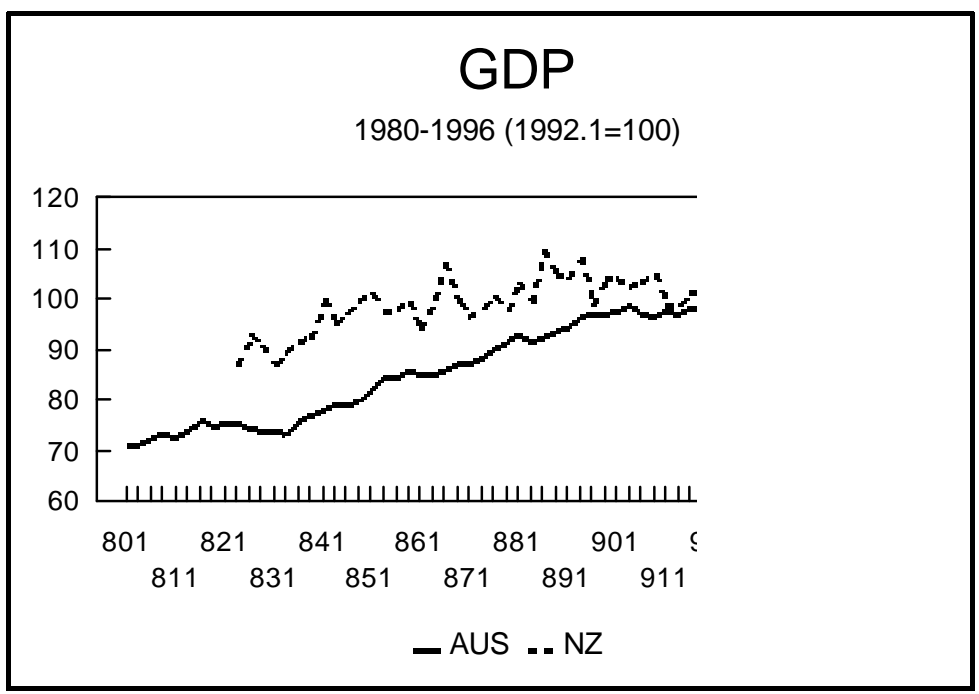

Figure 2

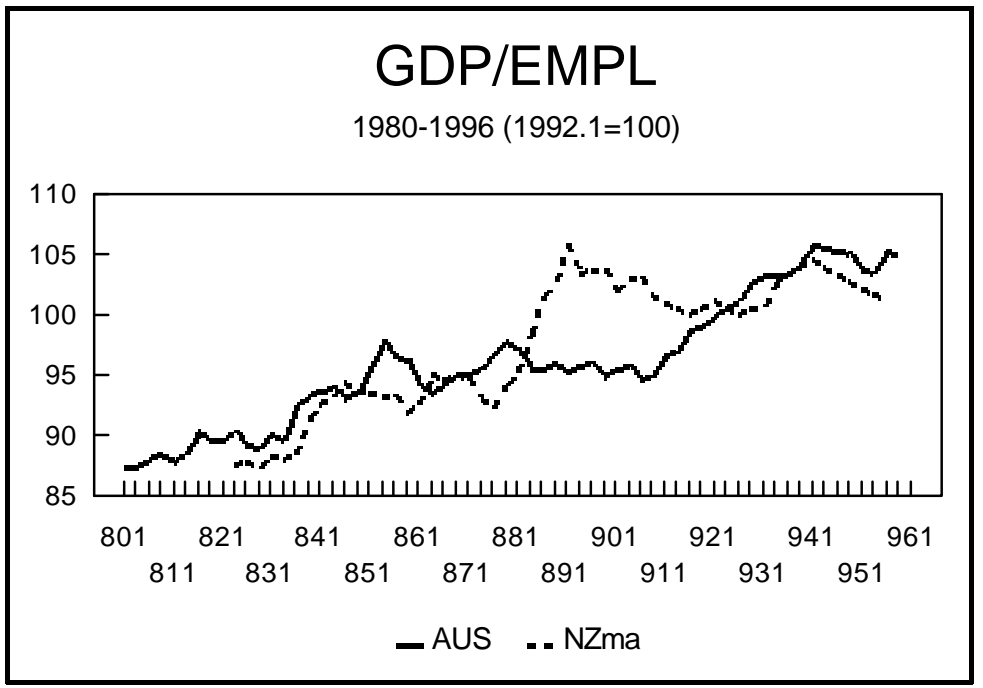

Figure 3

\section{REAL WAGES}

1982-1996 $(1992.1=100)$

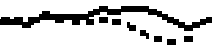

Ш山山шшш

1931941951961

-AUS .. NZ 
But investment has recently grown markedly stronger in New Zealand when compared to Australia. ${ }^{6}$ The recovery in 1991 in both countries was export led. However, while in New Zealand investment expenditures were an important contribution to further economic growth, the important factor in Australia was consumption. Both countries had a good export performance with an increasing share of manufactured goods. The current account has improved strongly in New Zealand in the mid-eighties, due to productivity increases and a decline in the nominal exchange rate, although it still shows a deficit. ${ }^{7}$ The deficit in Australia is higher, but this is mainly due to the costs of accumulated foreign liabilities. ${ }^{8}$

The development of productivity growth in both countries, measured by GDP per employee, is presented in Figure 2. Actually it was the poor performance of productivity in the 1970's, in particular in New Zealand, which was a strong impulse to the economic reforms in that country. But whereas in Australia productivity showed a rather steady increase over time, productivity in New Zealand surged in the late eighties, but stagnates afterwards. Important factors for productivity growth in New Zealand were the strong reduction in government subsidies to firms and the reduction of protection. ${ }^{9}$ These led to strong job shedding - of which one third through plant closures. An additional argument to explain the increased productivity is the privatization of state-owned enterprises that took place during that period (Harris and Daldy, 1995, p. 23-24). The stagnation of productivity in the nineties in New Zealand is surprising, since investment is relatively high.

Inflation has been lowered successfully in both countries in the early 1990's, after a relatively high inflation in the 1980's. In both countries low wage increases played an important role, accompanied by a restrictive monetary policy. The low rate of wage increase can also be seen in Figure 3. It is remarkable that these developments occur under totally different conditions on the labour market. In Australia the spread of enterprise bargaining, linking wage outcomes to productivity gains, has been limited. Other wages virtually faced a stand still since April 1991 - only low paid workers received modest increases due to the role of the Australian Arbitration Commission. In New Zealand on the other hand, no centralized bargaining or arbitration occurs and nominal wage growth was below productivity growth due to low inflation expectations and large unemployment. This led to a decrease in the share of workers income in GDP. Australia's share can be seen to be rather stable after a dip in the late eighties. We discuss the developments on the labour market in more detail below.

6 During the eighties Australia and New Zealand had quite similar ratio's of investment to GDP, around 25 per cent. After an initial decline in 1990, the ratio of New Zealand rose to over 30 per cent in 1993, while that of Australia still is struggling back to its original level.

7 Compared to Australia, New Zealand has also benefitted much more from the Australia - New Zealand Closer Economic Relations Trade Agreement (CER) which came into effect in 1983. Cf. BIE (1989).

8 These foreign liabilities might partly reflect the large investment opportunities provided by Australia's rich natural resource endowment (OECD, 1994A, p. 34). In this respect it is interesting that Kelsey(1995) notes that "Whereas in the 1980's balance of payments deficits had been covered by overseas borrowing, they were now being met by overseas purchases of government stock and sale of New Zealand resources to foreign buyers, few of which added to the productive base of the economy - and the profits from which went mostly offshore.”(p. 249).

9 In 1981/82 the effective rate of assistance to industry was 49 per cent in agriculture and 39 per cent in manufacturing. These rates declined to -6 and 19 per cent, respectively, in 1989/90. Cf. Harris and Daldy (1995), Table 2.2. See also Castle and Haworth (1993), pp. 32-33. 
When comparing Australia and New Zealand one should keep in mind that the population of Australia is about 18.5 million whereas that of New Zealand is about 3.5 million.

While the labour force increase steadily at a rate of 2 till 3 percent per year in Australia in the eighties, it was virtually stagnant in New Zealand in the second half of the eighties. However, relative to the labour force, employment has increased faster during the last recovery in New Zealand and hence unemployment decreased more when compared to Australia - cf. Figure 4.

Figure 4

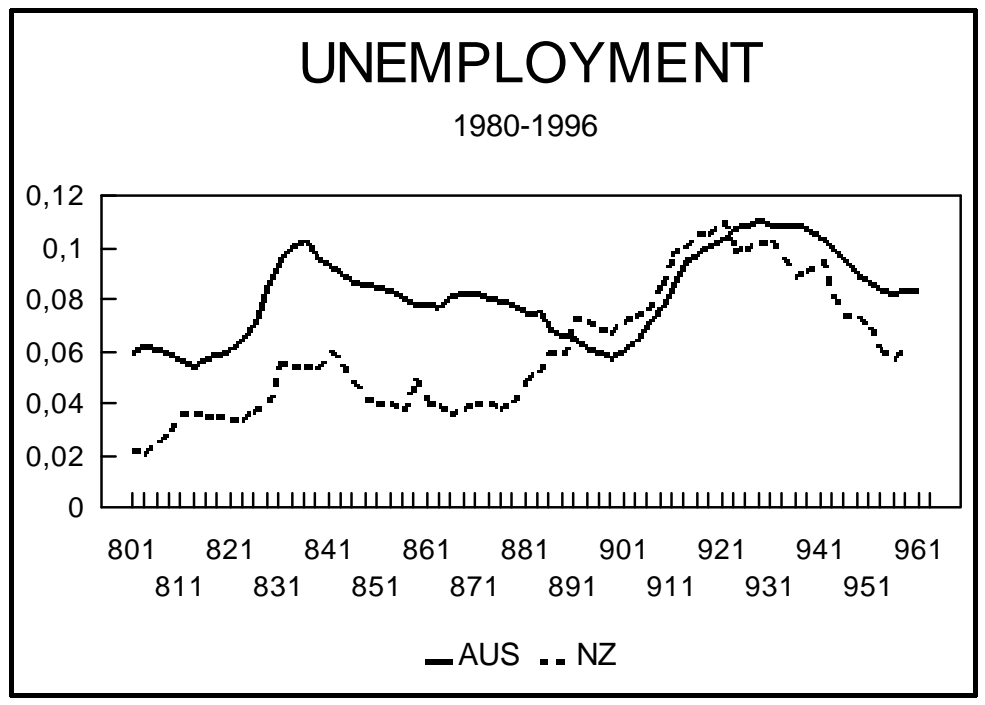

The upswing in New Zealand can be explained on the one hand as a consequence of the introduction of the Employment Contract Act, which implied a strong deregulation on the labour market. ${ }^{10}$ On the other hand it can be seen as a natural reaction to the preceding dip in employment (Rasmussen cs., 1985). Furthermore, the somewhat better performance of New Zealand when compared to that of Australia might partly be explained by the tradition of a more active labour market policy in New Zealand. However, Australia is catching up on that. ${ }^{11}$

Also some scepticism with respect to the decline in unemployment can be expressed due to the interchange ability between the different kinds of benefits. Hince and Harbridge (1994) point to this and

10 Kelsey (1995, pp. 264 - 266) points at the corresponding deterioration in the quality of new work. An example is the enormous increase in part-time jobs: "In the year ended March 1992, an average of 92,400 people employed part-time wanted to work additional hours. Yet part-time work increased 11.1 per cent in the year to February 1994, compared with 5.6 per cent for 30 hours a week or more." (p. 265).

11 A comparison of Chart 6.5, p. 101 of the OECD-Jobs Study part 2 shows that whereas Australian expenditures on active labour market measures, relative to GDP, in 1985 was about half that of New Zealand, the expenditures relative to GDP were equal to that of New Zealand in 1992. 
emphasize that the system in New Zealand itself encourages such a bias. The total amount of benefits in New Zealand has risen steadily, also in 1993, in spite of the registered decline in unemployment. ${ }^{12}$

With respect to the incidence of unemployment, one should realize that in New Zealand a substantial part of unemployment is concentrated with the Maori's and Pacific Islanders. They constitute nowadays almost one-third of total unemployment and almost half of long-term unemployment, while they represent about $12.5 \%$ of the labour force. ${ }^{13}$ The unemployment rate of males in this group did rise from 7.1 percent in 1985 to 26.7 percent in 1992 - the comparable figures for the other males are 2.5 and 8.5 per cent, respectively. ${ }^{14}$ In Australia, the Aboriginals also are relatively high unemployed. However, they are a much smaller group relative to the total population (about 2 per cent).

\subsection{Government expenditures and taxes}

With respect to government finance, it is remarkable that the share of government expenditure in GDP is consistently higher in New Zealand. In this country the share increased from 25 per cent after the first oil crisis in 1974 till almost 40 per cent in 1992, and is slowly decreasing now. In Australia on the other hand it increased from 22 per cent after the first oil crisis till almost 35 per cent in 1986, decreased sharply till below 30 per cent in 1989, and increased again till 34 per cent in 1992. The recent increases in both countries are caused to a large extent by the rising social security outlays due to the increases in unemployment in the late eighties and early nineties. The shares of transfers in government expenditure in Australia and in New Zealand are more or less equal at 38 per cent.

With respect to the budget deficit, Australia used to have a smaller deficit than New Zealand - in the eighties it even frequently had a surplus. As a consequence the ratio of gross debt to GDP was 11.6 per cent in 1992 in Australia and 64.2 per cent in New Zealand. Hence it is not surprising that the New Zealand government is urgently trying to reduce budget deficits and even created a surplus last year, while the Australian government used government expenditure programmes to stimulate the economy.

12 Similar remarks can be found in Kelsey (1995), p. 260 - 262. She also points out that next to data on unemployment, official data are available on 'jobless' people (without a job and wanting one, but not - or no longer - actively seeking work). The rate of jobless people (including unemployment) lies consistently 3 - 4 per cent points above the rate of unemployment.

13 Deeks, Parker and Ryan (1994), Table 16.3. The participation rate is almost similar to that of the other population groups.

14 Harris and Dadley (1994), Figure 3.6. This is partly due to the enormous reduction of the workforce of this group in manufacturing. 
Table 1 Tax-structure

\begin{tabular}{lcccccc}
\hline & 1973 & $1980^{*}$ & 1986 & 1989 & 1990 & 1992 \\
\hline $\begin{array}{l}\text { Australia } \\
\quad \text { Income tax/total } \\
\quad \text { Income tax rate } \\
\quad \text { low }\end{array}$ & 40.5 & 44.0 & 45.5 & 43.1 & 41.4 & 40.9 \\
$\quad$ high & & & & & & \\
$\quad$ Corporate tax rate & & & 21.0 & 21.0 & 20.0 \\
& & & 49.0 & 47.0 & 47.0 \\
New Zealand & & & 39.0 & 39.0 & 39.0 \\
$\quad$ Income tax/total & 70.9 & 75.2 & 74.2 & 65.5 & 63.5 & 62.0 \\
$\quad$ Income tax rate & & & & & & \\
$\quad$ low & 7.8 & 14.5 & 20.0 & 19.5 & 24.0 & 24.0 \\
$\quad$ high & 50.0 & 60.0 & 66.0 & 40.5 & 33.0 & 33.0 \\
$\quad$ Corporate tax rate & 45.0 & 45.0 & 48.0 & 33.0 & 33.0 & 33.0 \\
\hline
\end{tabular}

* 1981 for New Zealand

Source: OECD-Country Studies

There is a remarkable difference in tax structure between Australia and New Zealand, as can be seen from Table 1. Till the mid-eighties, New Zealand relied predominantly on income taxes, which constituted over 70 per cent of total tax receipts, whereas Australia the corresponding figure rose from 40 percent in 1974 till 45 per cent in 1986. The tax reforms in the late eighties in New Zealand implied a shift towards higher indirect taxes. Moreover, the tax structure changed radically, as can also be seen from Table 1: in the periods 1973 - 1990 the tax rate on low incomes increased from 8 per cent till 24 percent, while that for high incomes decreased from 50 per cent to 33 percent, after an initial increase. More information on these reforms is provided in Figure 5, where one sees the evolution from a differentiated tax structure in 1982 to a two-rate system in 1988. It is obvious that these reforms, and the increasing share of indirect taxes have increased income inequality in New Zealand. Moreover, as can be seen from Table 1, the tax reforms in Australia have been much more modest. Recently Australia has postponed a further reform of income tax and it has increased its corporate tax rate again to its original level of 39 per cent, after a brief decrease to the New Zealand level of 33 per cent. 
Figure 5

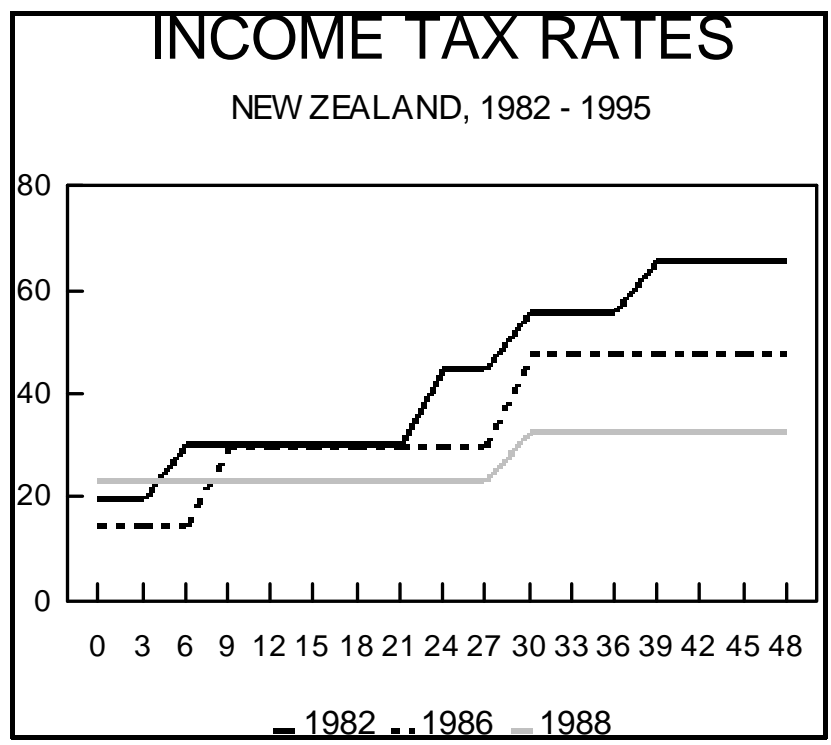

\subsection{The income distribution}

It is hard to find data on inequality in incomes for New Zealand. The Economist of November 5th, 1994 presented data showing that New Zealand was the third country in the income inequality league with America being first and Germany ninth and the Netherlands tenth. Surprisingly enough, Australia was second in this table! Income inequality is measured by ratio of income of $20 \%$ richest of households to $20 \%$ poorest. However, when we look at the inequality measures presented in Table 2, one finds a different picture. The highest after-tax income deciles in both Germany and the Netherlands exceed those of Australia relative to the middle decile, whereas with respect to the lowest decile women are somewhat better off in Australia and men somewhat worse. The overall picture suggests that inequality in Australia is certainly not larger than in both Germany and the Netherlands. The difference with the USA is evident and comparable to that reported by The Economist. One also sees that the development between 1981 and 1990 shows that the income distribution has remained stable in Australia. An indication of the development of the income distribution in New Zealand can be obtained from the real disposable indices for full-time wage and salary earners. These indices are published amongst others in each issue of the Statistical Yearbook of New Zealand. 
Table 2 Measures of income inequality

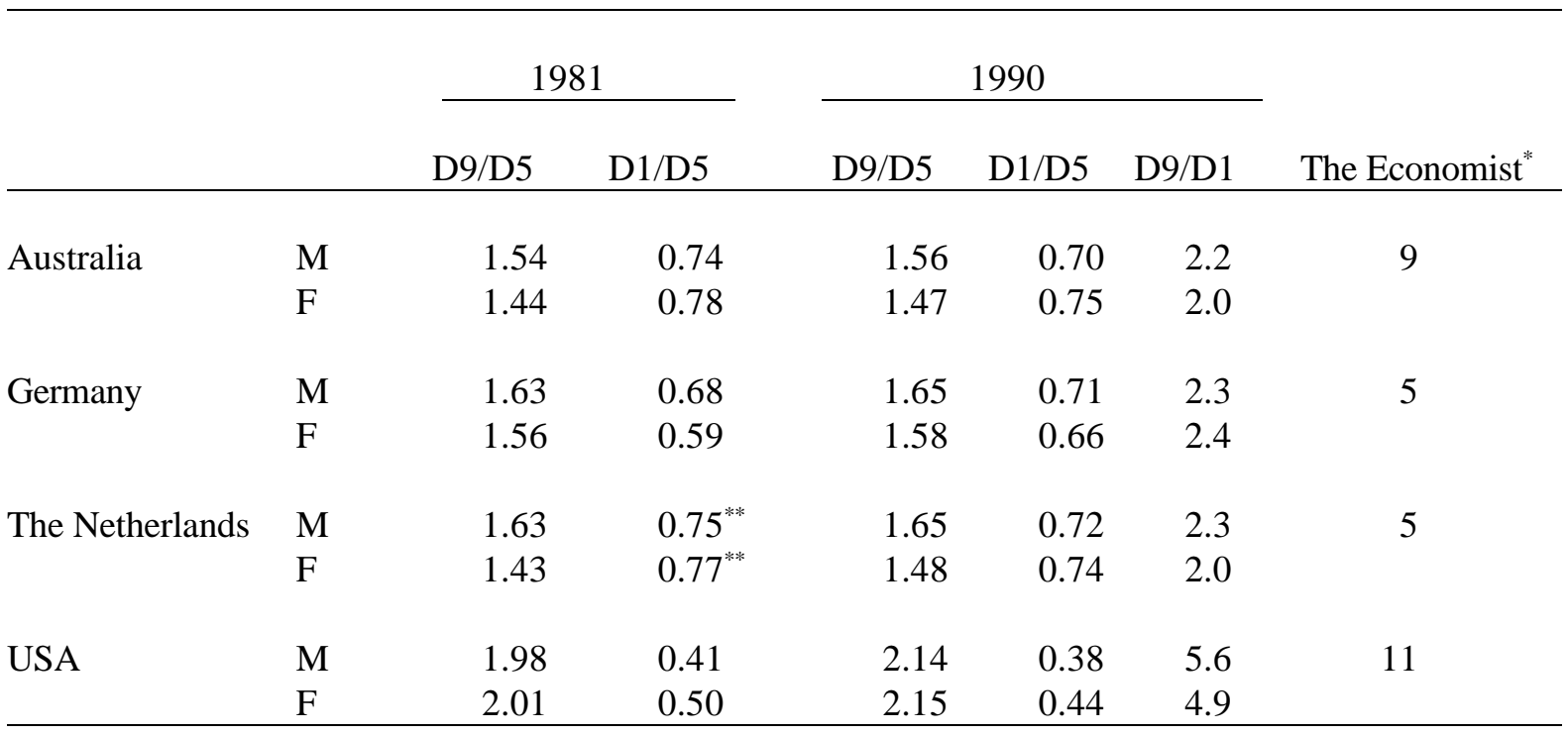

Note: D9 refers to the highest income decile, D5 to the middle one and D1 refers to the lowest decile.

* Male and Female

** 1985

Source: OECD-Employment Outlook 1993, p. 160; The Economist, Nov. 5, 1994, p. 20.

Based on 1980 as a base year indices are calculated for the lowest 20 per cent income group, the middle 20 per cent income group and the highest 20 per cent one. The development of these indices over time is depicted in Figure 6 for the period 1983-1993. ${ }^{15}$ From the figure one sees that the 1982 tax changes, depicted in Figure 5, led to a strong relative increase of the highest incomes. The differences then declined somewhat, but the 1986 tax changes led to another relative increase of the highest incomes. Finally, the 1988 tax changes led to a sharp increase of the highest incomes, which is still characteristic for the present situation. From Figure 6 and Table 2 two interesting observations can be made. ${ }^{16}$ In the period 1980 - 1993 both low and middle disposable income have not increased over time, it is only the highest income group that has experienced a growth in real disposable income since 1980. And whereas the income distribution in Australia has remained relatively stable, that of New Zealand has shown a strong increase in the position of higher incomes, relative to both the middle and lower incomes. The latter incomes actually declined in New Zealand. ${ }^{17}$

15 See also Hince and Harbridge (1993), Table 3.

16 Both Table 2 and Figure 6 refer to after-tax disposable real incomes. However, whereas the data for the countries presented in Table 2 refer to after-tax real household incomes, those for New Zealand, presented in Figure 6, refer to real disposable incomes for full-time wage and salary earners. Hence the relatively low incomes of part-time workers and unemployed are not included. Therefore the data on low incomes in Figure 6 are biased upwards. Finally, the data in Table 2 refer to income deciles, whereas those of Figure 6 refer to 20 per cent ranges.

17 Kelsey (1995, p. 256 - 259) provides more detailed information on the New Zealand situation. Amongst others she states: "The real spending power of those in employment between 1987 and 1992 rose by 7 per cent for the wealthiest 20 per cent and fell by 2.9 per cent for the poorest quintile."(p. 258). 
Figure 6

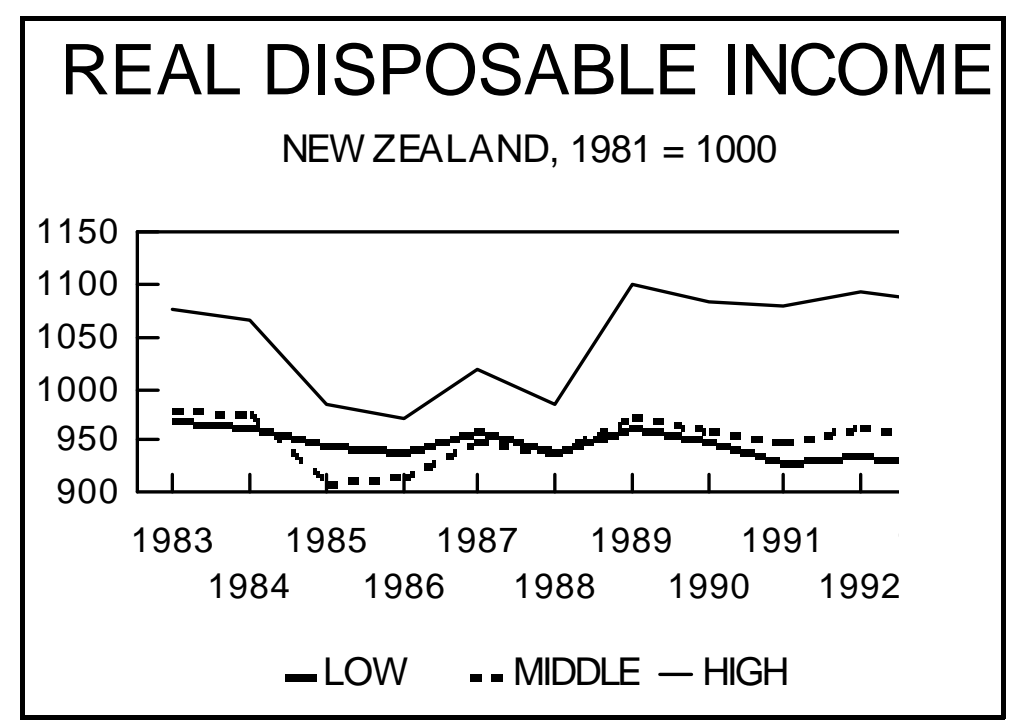

As is indicated in the Statistical Yearbook, the tax reforms played an important role in this development. And the further shift towards a higher share of indirect taxes will exacerbate this development. Moreover, one may expect that the Employment Contracts Act will also lead to a larger wage dispersion. Finally the absence of income growth for low and middle incomes is consistent with the stable development of real wages, cf. Figure 3, and the declining share of workers income in GDP.

When one looks at unemployment replacement rates on an after tax basis, a remarkable difference can be observed in the development over time between Australia and New Zealand. Whereas in the former country the replacement rate increases over time - from 18 per cent in 1961 till 32 per cent in 1991 - this rate decreases in New Zealand - from 46 till 31 per cent. Hence, in 1991 both rates are more or less comparable. However, one should remember that the real income levels in New Zealand are lower compared to those in Australia, and hence the benefits are too (OECD, Jobs Study II, p. 226). Moreover, in 1991 a severe cut in the benefits took place in New Zealand. Kelsey (1995, p. 277) reports that while household income of beneficiaries was 72 per cent of the mean equivalent disposable household income in 1990, this decreased to 58 per cent in 1993. While in the top quintile of beneficiaries no group lost more than 4.6 per cent, the bottom 20 per cent experienced a loss of between 13 and 30 per cent in disposable income. ${ }^{18}$ The brunt was borne by Maori and Pacific Island people, women and elderly people.

18 Although poverty can only be measured in a relative way, Kelsey mentions a study by Easton who found that the percentage of people below the poverty line increased from 11.6 per cent in 1981/82 to 12.9 per cent in 1989/90 and then to 16.3 per cent in 1992/93. And she mentions a study by Stephens who used a different method and found 17.8 per cent of people below the poverty line in 1991. For an elaborate discussion of the measurement of poverty see Easton (1995). 
From the analysis above, we infer that the claim of The Economist that New Zealand is gaining a long term economic edge over Australia cannot be substantiated. GDP growth in New Zealand did only recently pick up and is now similar to that of Australia. New Zealand does certainly not perform better in this respect and its GDP per capita is still 15 per cent lower than that of Australia.

The rate of unemployment is somewhat lower in New Zealand - measurement problems may confuse the comparison, however. Moreover, in terms of employment growth the record of New Zealand is much worse than that of Australia: Employment in New Zealand is now back at its level of the mideighties, whereas that of Australia has grown steadily.

With respect to government finance, New Zealand indeed has a surplus on its budget. However, its debt amounts to almost 65 per cent of GDP, whereas that of Australia is about 12 per cent. Hence Australia can afford to have a budget deficit in order to boost economic growth, although it should not abandon its prudent behaviour of the past which led to such a low debt. New Zealand on the other hand with such a high debt has hardly any other choice but creating a surplus on its budget.

When looking at the situation in New Zealand some other aspects should be taken into account too. One of the elements of the reforms has been a drastic change in the tax structure. On the one hand the tax rates for higher incomes have been lowered considerably, while on the other hand indirect taxes have increased. As a consequence of these changes, the income inequality increased strongly. Only the higher disposable wage-incomes have increased over time while the lower and middle incomes remained at the same level as in 1980. In Australia the distribution of income has remained more or less stable since 1980. Hence all incomes shared equally in economic growth.

Finally the introduction of the Employment Contracts Act in New Zealand will lead to a larger wage dispersion and hence to a further inequality in incomes. This may lead to a lot of social unrest. Moreover this Act will cause a lot of social unrest in other respects - many vital aspects of the welfare state are at stake. ${ }^{19}$ We will come back to that in section 4.

In conclusion, the recent favourable economic situation in New Zealand does not out perform that of Australia. The Economist's claim that "New Zealand is gaining a long term economic edge over Australia" due to the tougher stand on economic reforms in New Zealand, therefore cannot be substantiated. Any claims in that respect remind us of the story of the mouse who walks over a wooden bridge together with an elephant and remarks: "How nice we are stamping together".

\section{Economic performance and the welfare state}

3.1 Introduction

If a particular society is in trouble, conflicts can have economic, social or political origins. When, as was the case with New Zealand and many Western European countries, bad economic performance was the main reason for thinking about reform, the main task of their reform policy is to make the welfare state more efficient. But the characteristics of the most desirable combination of instruments are not only determined by economic, but also by social and political restrictions. Ignoring economic restrictions will

19 The influence of all these measures on the social situation in New Zealand is documented in a concise way with a disconcerting impact in Kelsey (1995) chapter 11, titled 'The Social Deficit'. 
make the imbalances with respect to the governmental and national budgets more severe, that is obvious. But ignoring social or political restrictions will create other imbalances, which may have repercussions on economic performance too. This should be considered very carefully when reforming the welfare state.

One should realize that the origins of the welfare state stem from the notion that a market economy is characterized by potential conflicts between capital and labour, between large and small corporations and between high skilled and low skilled labour. Besides that a group of outcasts will be a constant threat. All these elements lead to social restrictions. The welfare state then can be considered as an efficient way to regulate these conflicts and to avoid this threat. A reform policy aiming at a strong slimming of the welfare services may lead society back to more conflicting times. Collective strategies may lead to wild strikes, time consuming protest meetings, huge increases of lobbying activities, etc. Constant social unrest can also inspire individual strategies of shirking and criminality in the firms that cause productivity to increase less than otherwise would have been the case. To avoid all these costs it is efficient to take the dominant values and norms into account. This implies that the welfare state has to be consistent with the prevailing culture in a society.

A special part of the social relationships in a particular country is the polity. Political relationships must be taken into account explicitly, because they are of special importance for the decision making with respect to the welfare state. Therefore another restriction when determining the optimal reform strategy is the political restriction.

These considerations imply that the nature of the welfare state, and hence also the kind and magnitude of eventual reform policies, do not only depend on the economic situation, but also on the social and the political situation. Although this may seem obvious, it is not always recognized that social and political restrictions should be considered explicitly when analysing the welfare state. Or when their importance is recognized, how these restrictions should be included in the analysis.

For that reason we will elaborate the relationship between social and political constraints and the welfare state below. But before doing so we will first give a more precise description of the concept of the welfare state and elaborate on its function in democratic societies.

\subsection{The nature of the welfare state}

The history of capitalism teaches us that a full fledged market economy is not beneficial for all people. ${ }^{20}$ In the nineteenth century, when the countries liberated their economies from government regulation, economic growth and large scale poverty developed simultaneously. To resolve the resulting labour versus capital conflict, during the first half of the twentieth century various grand political compromises were formulated. ${ }^{21}$ The policies based on such a kind of policy appeared to be the corner stones of what is called 'the welfare state' now. Almost all countries adopted a kind of Keynesian oriented stabilization policy. Also some countries adopted a system of collective bargaining, including governmental income policies as a necessary complement. In some countries severe mismatches on the labour market were

20 One should realize that it is not only history that provides these insights. The failure of a pure market economy has also been argued forcefully by, for instance Sen (1987) who argues that the building up of a more democratic system of human rights (immaterially as well as materially interpreted, i.e. co-determination as well as universal systems of education, health care etc) was and is the instrument to transform inefficient conflicting behaviour into efficient cooperative activities. 
diminished by means of active labour market policies within the framework of a number of legal restrictions with respect to age, safety and the like. And in many countries the establishment of a number of social funds for those who are not able to earn a living by themselves, were introduced as a safety net. ${ }^{22}$

We can also see from history that if the institutions are only the result of a political compromise, and are interpreted by all parties as 'not exactly what we wanted', then in fact a society is not able to develop a social consensus about the main principles of it. Nobody is really willing to commit himself to the rules of that particular welfare state game. Political leadership is constantly trying to make the voters clear that the system is unfair and must be improved. In that case no form of the welfare state is viable, since it is not consistent with the prevailing cultural and political views. ${ }^{23}$ What essentially is needed is a consensus on the main principles of liberty, equality and brotherhood. Then we find welfare states that are sustainable because they are adjustable to ever changing situations, but that also meet the economic and social standards that are formulated by the culture of a particular country. Internally consistent, socially and politically acceptable and economically payable.

From the discussion above, the nature of the welfare state can be interpreted in a broad way. The following list intends to enumerate the possible functions of the welfare state, in order to define its relevant characteristics. ${ }^{24}$

To start with, economic stability is a widely recognized aim. A problem then is that a free market economy, once in a deep depression may not have the mechanisms to recover. ${ }^{25}$ This means that the government should manage effective demand - either by monetary or by fiscal policy - in such a way that deep depressions are avoided.

Another instrument to improve efficiency and fairness of a capitalist society, is the introduction of a system of collective bargaining. ${ }^{26}$ Because the combination of Keynesian demand management and a system of collective bargaining may give the unions too much power, the government can decide to develop income policies to restrain wages. ${ }^{27}$

Not only on the macro level, but also on the micro level a free market economy can show severe imbalances, to wit mismatches between demand for and supply of labour. The government can develop

In some cases 'pragmatic' reasons dominated - cf. Bismarck, who linked social security direct to employment and work - and in other ideological reasons - cf. Beveridge, who insisted on availability of social security for everybody. Cf. also Barr (1993), Ch. 2.

23 Cf. section 3.4. See also Barr (1993, p. 284) who states: "Reform is likely to be hampered by the political difficulties which can beset even small changes ...".

24 A larger set of objectives of the welfare state is presented in Barr (1993), Ch. 2.2. However, each of these objectives can be categorized under one of the characteristics mentioned in our list. See also Lindbeck (1994) and Snower (1994). As we shall see later in some views about how to build an efficient welfare state some characteristics are considered to be undesirable.

Interesting in this context is the discussion about the restructuring of the economy in Eastern Europe. Various authors point at the danger of hysteresis, i.e. the economy might get stuck at a lower level, when implementing drastic measures. Cf. Barr ed. (1994) and De Neubourg (1994). 
so-called labour market policies to diminish these kinds of mismatches. ${ }^{28}$ This should be balanced against minimum standards which are set to protect workers against too harsh labour market conditions.

Finally an obvious function of the welfare system is to produce a number of social services for vulnerable and marginal groups in society, such as the very young, the very old, the unemployed, the ill or handicapped people. The social system is characterized by various aspects: its extensiveness, its generosity, its focus on equality and the extent to which the system is monitored. ${ }^{29}$

It is useful to elaborate these last points, since they are distinctive features of a welfare system. First of all we can look at the extensiveness of the system. This defines under which circumstances persons can participate. Can anybody participate who is unable to earn his or her own living? When is this considered to be the case? Are benefits provided to unemployed, is insurance provided to ill people?

In the second place we can look at the generosity of the system. This indicates the rights for the participants, and the scope of goods and services provided to them. In some situations there are only very limited assistance benefits for those who can prove to be unable to earn their own living. Illness insurance, disability insurance, free health care, free education up to a particular age, pensions, subsidies for housing, can also be part of the package, although it is not necessarily the case in all welfare systems. Moreover, some systems are characterized by high benefit rates and low own risk contribution, while other systems are less generous in defining rights for the participants.

In the third place a system is characterized by the extent to which it has to contribute to equality. Is the aim a fair income distribution or is the system just an expression of some paternalism: individuals are enforced to secure themselves for a number of unbearable risks. In particular the way how the financing system is organized, is influenced by the ideology behind the system.

In the fourth place we can mention the way the social rights and duties are monitored. Tight monitoring is costly and only beneficial if one expects widespread misuse in case of low monitoring efforts. A disadvantage of monitoring is a violation of the privacy of the benefit receivers. In a liberal society permissiveness is mostly the result. If we want to rebuild social morality, tight monitoring may be an effective weapon. ${ }^{30}$

These are the features we will use to characterize the welfare state according to various cultural dimensions and political views, cf. Tables 3 and 4 below.

28 There is a huge literature on the merits and shortcomings of active labour market policy. Although different features are emphasized by different authors, the outcome rather consistently is that active labour market policy should be pursued in one form or another to combat unemployment. See for instance Calmfors (1995) and Robinson (1995).

29 For sake of brevity we will further ignore another distinctive feature below, the parties involved in the organization. It can be owned and organized by the union, or by a cooperation of unions and employers' organizations. The government can do it all, but in many cases the system is tripartitely managed: workers, employers and government.

30 As is the case with the use and the financing of social funds, all the other types of policies mentioned above can also be subject to fraud. Politicians who are serving their own interests, may use fiscal policy instruments for their re-election purposes. And the same can be said of income policies, labour market policies and the system of collective bargaining. It appears to be extremely difficult to let such policies and systems function according to the original intentions, focused on the serving of the intended general interest. 
When looking at the institutions from a social point of view, we can ask whether a particular social situation can be considered as integrated. Or is there a process of social disintegration going on? Perfect integration then means that all individuals and groups are perfectly satisfied with respect to the existing social order. Imperfect integration then means that individuals and/or groups are not perfectly satisfied and are developing strategies to change that order. Activities to change a particular social order can have an important effect on the economic performance of a country.

In analysing the social situation further we should distinguish between two different dimensions. On the one hand we have to consider the structural dimension. The focus then is on the structure of society, including the economy. For individuals their concrete position in society is part of the structure. On the other hand we should take into account the cultural dimension. ${ }^{31}$ This dimension reflects the norms and values shared by the people. It is the basis of the opinions and attitudes of individuals. It is obvious that if a structure would be in perfect harmony with the prevailing culture, then the social world would be in equilibrium..$^{32}$ The difference between the two are the informal patterns that exist in every organization, including society. And when the difference becomes too large, tensions will arise which may result in social action. It therefore is important to try to identify both the structural and the cultural dimension in a society.

Of the various structures that can be distinguished, the welfare state is a principal one. Its features have been elaborated in the previous section. However, the differences between the various welfare states may reflect variations in culture. When we consider the culture as the demand for a particular social structure and the social structure itself as the supply for this good, then we can define social equilibrium as the situation in which demand is equal to supply - then structure and culture perfectly reflect each other. In case of a cultural lag, structure has to be adapted to culture and hence reflects culture. So we must find a classification of different cultures that can be related to a particular welfare state structure.

We have found a very useful classification of cultures in Hofstede (1980). He has designed four cultural dimensions, determining the attitude of groups. The concepts developed are operationalised and empirically measured world wide. We will describe them shortly and also link them to the structural characteristics of the welfare state.

The first dimension is called Uncertainty Avoidance and reflects the degree to which people are willing to avert risk and uncertainty. Although nearly all people are inclined to reduce risk, the difference in cultures can be described to what extent and in which way cultural units are inclined to reduce risk and to avoid high levels of uncertainty. With respect to the various characteristics of the welfare state we can say that risk reduction is a core element. Full employment policies as well as social securities are primarily focussed on the improvement of the chances of all people to get a job and/or an income.

31 These dimensions also broadly reflect two different views in sociology: the conflict view, which traces back to Marx and Weber, emphasizes the structural dimension, whereas the consensus view, going back to Durkheim, focusses on the cultural one. This is elaborated in Stark (1994).

32 Essentially a similar point is made in Jones (1995), where he discusses culture and its relationship to economic change. Jones rejects rightly on the one hand 'Cultural Nullity', which denies any economic significance of culture, and on the other hand 'Cultural Fixety', which assumes that culture encompasses economy and changes autonomously. He then argues in favour of 'Cultural Reciprocity', seeing culture as a process which interacts with the economy, although with sometimes considerable lags. 
Therefore we think there must be a positive relationship with all characteristics of the welfare state, except with respect to 'generosity' and 'equality'. These two characteristics have no relationship with respect to uncertainty avoidance; they only affect the level of welfare services offered by the state. ${ }^{33}$

The second dimension is called Masculinity and reflects a set of values that are attached to the male archetype. The opposite is called femininity, reflecting the typical feminine values. In general we can relate masculine elements to the capacity to rival whereas femininity has to do with cooperation and care. Hence relating this to the welfare state characteristics, masculinity could imply that all systems, including care systems must be tightly monitored. ${ }^{34}$ However, extensiveness, generosity and equality, all focussed on participation of the poor, must be considered as typical female aims. Therefore the relationship with masculinity must be a negative one.

The third dimension is called Individualism and reflects the degree to which an individual thinks in terms of 'I' or 'WE'. The opposite of individualism is called collectivism. With respect to the ultimate aims of the welfare state we can imagine that individualism implies the production of more individual freedom and more equal opportunities between individuals, whereas collectivism requires from a welfare state a contribution to stable stratification patterns and order. ${ }^{35}$ When we relate this dimension to the welfare state characteristics, we must conclude that a low score on individualism implies a low score on equality and a high score on monitoring and collective bargaining. A high score on individualism does not lead us to clear-cut conclusions. The classical liberal as well as the Continental liberal view, as distinguished by Hayek, is based on individualism. ${ }^{36}$

The fourth dimension is called Power distance and reflects the distance people expect, perceive and accept between the various ranks in society and in their work organizations. In earlier times hierarchical views were common in most cultures. But a few centuries ago some people started to think in terms of individuals and equality. All people must be regarded as equal to each other, irrespective the differences we can observe. Hierarchy must only be regarded as an efficient coordination mechanism and has nothing to do with differences in terms of human dignity. With respect to the characteristics of the welfare state we can say that countries with a high score will strive for a rather conservative welfare state. Social stratification must be maintained by the introduction of welfare services. This means that the system must be characterized by low scores on equality, extensiveness and generosity. With respect to monitoring a high score must be expected. ${ }^{37}$

33 It seems plausible that all other characteristics are related to uncertainty avoidance, since a typical aim of the welfare state is the reduction of risk. See., for instance, Sinn (1995) and Barr (1993, Ch. 5).

34 This is strongly visible in the extreme example of state corporatism: a fascist system. Its characteristics are the corporatist structure, dominated by the state, whereas the state is ruled by a strong leader, who is necessarily a man. The role of women is to care for children. Cf. van Putten (1985) and Williamson (1989).

35 In terms of Berlin (1969) there is a debate between negative and positive freedom. 'Negative' means the absence of governmental coercion. 'Positive' means the presence of resources necessary to make use of negative freedom. None of these interpretations can be excluded from Hofstede's individualism, if we analyse the concepts carefully. Nevertheless, we think that most persons who had to fill in the questionnaires in the Hofstede's research had the 'negative' freedom concept in their minds when thinking about individualism.

Hayek (1978).

37 Monitoring or policing activities, interpreted as supervision, is a central element in an hierarchical structure. So we can expect a positive relationship between monitoring and hierarchy and power distance. Cf. 
In Table 3 we have summarized our notions in a matrix with scores reflecting the relationship between the cultural dimensions on the one hand and the various characteristics of the welfare state on the other hand. We can use this table to look whether a particular form of the welfare state in a society coincides sufficiently with the culture as measured by the Hofstede dimensions. And we will do this for New Zealand in section 4.

An alternative way of finding such a match between culture and structure is taking an empirical approach. One can perform a cross-country study of many countries by using the Hofstede scores for these countries on the one hand and somehow scoring the various features of the welfare state on the other. This is similar to the approach of Esping Andersen which we discuss in the next section. However, there are two problems in such an approach. First it is very difficult to find proper measurements for the various features of the welfare state. The variety of indicators and different results found in studies of for instance corporatism is a clear example of the difficulties one will encounter. ${ }^{38}$ To find a proper indicator for each of the eight characteristics and measure these for a sufficient number of countries typically is a question for further research. However, it would distract us too much from our present analysis, in which we intend to present a framework in which such a more elaborate analysis would fit. The second problem with the empirical approach is that it requires rather strong assumptions on the balance between structure and culture. In principle one should assume that on average each country is in balance and measurement errors cancel out. Otherwise a lot of additional ad-hoc assumptions have to be made. It is for that reason that we stick to the case study approach in the present paper. And since our aim is to present a framework for analysis, we restrict ourselves to one case only, New Zealand, which is discussed in section 4.

Table 3 Culture and type of welfare state

\begin{tabular}{lcccc}
\hline & $\begin{array}{c}\text { Uncertainty } \\
\text { Avoidance }\end{array}$ & Power Distance & Individualism & Masculinity \\
\hline 1 Stabilization policy & 3 & - & - & - \\
2 Income policies & 3 & - & - & - \\
3 Collective bargaining & 3 & - & 1 & - \\
4 Regulation & 3 & - & 1 & 1 \\
5 Extensiveness & 3 & - & - & 1 \\
6 Generosity & - & 1 & - & 1 \\
7 Equality & - & 3 & - & 1 \\
8 Monitoring & 3 & 1 & 1 & 3 \\
\hline
\end{tabular}

Scores: 1 - disagree, low; 2 - middle position; 3 - agree, high.

Hofstede (1980). 
In a political democracy several political views compete with each other for the votes of the voters. The reform policy must be a reflection of the dominant political views, otherwise it cannot be successful. ${ }^{39}$ Essentially this can be considered to be another way of looking at the structural-cultural match discussed above. However, given the importance of the political decision making with respect to the welfare state this deserves separate consideration. ${ }^{40}$ For that reason we wish to pay separate attention to the relationship between different political views and the characteristics of the welfare state.

A fruitful starting point for our analysis is the distinction of Esping Andersen (1990) between three worlds of welfare capitalism. His classification is the result of empirical research, leading to three main clusters of specific characteristics.

The conservative cluster is based on the idea that a welfare system can contribute to the maintenance of the system of social stratification. A well educated, healthy and disciplined working class must be considered as an important interest of the state and of the elite, ruling that state. The structure of the welfare system must organize solidarity per stratum. That is, premiums paid and benefits received are dependent on the level of income or wealth, so as to avoid a process of leveling.

The liberal cluster is based on the idea that a welfare system is necessary only for those people who are evidently unable to earn their own living. Liberalism considers society as a set of individuals who are willing and capable to serve their own interests, better than anyone else. This means that everyone must be free to choose how to (trans)act. In a welfare state the government has the task to support those people who are really unable to transact, i.e. to give them a minimum of resources to live their life.

The social democratic cluster is based on the idea that modern capitalist production modes are a threat for social integration. A welfare state must keep society united by offering every individual the necessary resources to participate in society in every respect. Hence everyone has the right to vote, to receive proper education, to have a decent house, to have an appropriate job etc. Therefore Social Democrats are strongly in favour of all characteristics of the welfare state discussed above: extensive, generous, equalizing social funds, an organization in which the unions, the employer's organization and the government runs the welfare state, including the policies focused on stabilization, income and labour market regulation and collective bargaining. Tight monitoring appears not very popular in social democratic circles, because they interpret their role often as a pressure group in favour of the poor, that are mainly the users of the funds.

From the discussion above, we summarize the political views with respect to various aspects of the welfare state in Table $4 .^{41}$ The strong liberal reluctance is expressed by the six low scores. With respect to regulation a middle position is taken, because even according to liberal principles children,

39 In a multi-party system coalitions have to be formed, however. The disadvantage of coalitions is the difficulty of testing the efficiency of the various political views. If policies do not have the intended effects, every party can easily blame the other(s) for making the policies ineffective. Although these problems will be recognized by the public, persistent inconsistencies between the welfare state and a political view will erode the political support for that view.

40 In her discussion of the New Zealand reforms Kelsey (1995) distinguishes sharply between the economic, the social, the cultural and the democratic deficit - these are discussed in separate chapters.

41 Because we have defined the concepts 'liberal', 'conservative' and 'social democratic' according to Esping-Andersen (1990), there is a strong correlation between the empirical specifications of EspingAndersen en our welfare state characteristics. 
elderly and severely handicapped people must have the inalienable right to a decent living. ${ }^{42}$ With respect to monitoring they will be less tough than the conservatives, because individual privacy is highly valued in the liberal mode of thinking. The tough approach of the conservatives is also expressed in the high score for collective bargaining, regulation and extensiveness. ${ }^{43}$ But it also leads to low scores for generosity and equality, which is against the natural hierarchical order as perceived by the conservatives. As mentioned above, the social democratic view leads to a high score on all welfare state aspects, except monitoring.

Table 4 Political view and type of welfare state

\begin{tabular}{lll} 
Liberals $\quad$ Conservatives & $\begin{array}{l}\text { Social } \\
\text { Democrats }\end{array}$ \\
\hline
\end{tabular}

$\begin{array}{llll}\text { 1 Stabilization policy } & 1 & - & 3 \\ \text { 2 Income policies } & 1 & - & 3 \\ \text { 3 Collective bargaining } & 1 & 3 & 3 \\ \text { 4 Regulation } & 2 & 3 & 3 \\ \text { 5 Extensiveness } & 1 & 3 & 3 \\ \text { 6 Generosity } & 1 & 2 & 3 \\ \text { 7 Equality } & 1 & 1 & 3 \\ \text { 8 Monitoring } & 2 & 3 & 1\end{array}$

Scores: 1 - disagree, low; 2 - middle position; 3 - agree, high.

In a similar way as Table 3, Table 4 represents an equilibrium between the prevailing political view and the existing welfare state. However, contrary to Table 3 it is not mainly based on prior notions, but also on empirical observations - as has been elaborated in the discussion above. And as also has been mentioned above we will present in the next section the New Zealand situation as a case study to illustrate the appropriateness of our analysis.

\section{Lessons from New Zealand}

4.1 The nature of the welfare state

What we have only mentioned briefly until this point is that New Zealand was in a rather bad situation in the early eighties. It was hit very hard by both oil crises and suffered heavily from the fall in world trade. Its external debt was also very high. Hence some drastic measures were called for. This also explains the initial political success of Rogernomics. One should also realize that the reforms in New Zealand were very broad, the reforms of the welfare state were only one element of it.

42 Esping-Andersen's empirical specification of 'liberal' is the minimum pension as a percentage of a normal worker earnings, in an attempt to express the degree of de-commodification. In a liberal system the score is rather low, where in a social democratic system the score is rather high.

43 Esping-Andersen's main characteristic of a 'conservative' welfare state is its corporatist organization pattern. In his empirical measurement he takes as indicator the degree of status segregation, that is the number of distinct occupational and status based pension schemes. 
However, when we stick to the welfare state, the following observations can be made. Important were on the macro-policy side a tight monetary policy and efforts to reduce the budget deficit. Actually laws were passed like the Fiscal Responsibility Act and the Reserve Bank Act which severely restrict the room for fiscal and monetary policy. ${ }^{44}$ This implies that there was no active stabilization policy.

On the micro-policy side distinct features were a strong reduction of foreign trade restrictions, a deregulation of the goods market, leading to increasing competition, and tax reforms leading to larger differences in income. Hence there was no active income policy too. It is only more recently that the structure of the labour market was considered as an obstacle to economic growth and therefore the Employment Contracts Act was introduced in 1991. This Act was very controversial and figures in many descriptions as a symbol of the radical nature of the New Zealand reforms. ${ }^{45}$

An important feature of the Employment Contracts Act is that it bans any notion of collective bargaining and union representation. All bargaining should be decentralized, localized and enterprisebased. The impact of these reforms for collective bargaining and regulation on the labour market is clear. Moreover, the various features of social security have already been discussed in section 2.4. The extensiveness, generosity and equality typically have decreased strongly due to the reforms and have a low score. Finally monitoring has been tightened. ${ }^{46}$

The social situation

When we look at the culture of New Zealand, we use Hofstede's four dimensions, mentioned in section 3.3. And we also use Hofstede's observations, since he has made extensive surveys to characterize the cultures of various countries by means of scores for each of these four dimensions.

Actually, Hofstede has produced scores for 120 countries. ${ }^{47}$ There appear to be various interesting culturally homogeneous areas. For the Western world an important distinction can be made between the regions that were part of the Roman Empire (and related regions such as Latin America) on the one hand and areas that were not invaded or that canceled the cultural inheritance via the Protestant Reformation (Germany, The Netherlands, Scandinavia, Great Britain, USA, New Zealand!). The Roman culture is characterized by a relatively high level of power distance, collectivism and masculinity whereas the Protestant culture is characterized by relatively low scores on the dimensions just mentioned.

The measures for the New Zealand culture are presented in Table 5, together with those of Australia. To give the scores a better perspective, the scores for Great Britain, The Netherlands and the

Essentially the FRA implies the requirement to maintain a surplus-driven, low debt regime. And the RBA defines price stability as the sole aim of the Bank: inflation should be consistent with the Policy Targets Agreement - currently a median value of 1 percent.

An elaborate description of this Act and its background is given in Kelsey (1995), Ch.8.

46 Kelsey (1995) p. 290 ff. reports on this. Amongst others she argues how targeting of social services required the proof of entitlement by citizens - amongst others various kinds of community services cards were issued. Moreover, the increased privatization of social services led to a decreased political control of the accessibility of these services.

47 The results for 40 countries are presented in Hofstede (1980), p. 315. 
USA are added, together with the average score for 'European' countries and their standard deviation. ${ }^{48}$ When compared to Australia, New Zealand is somewhat less individualistic and has a smaller power distance. And except for uncertainty avoidance, Australia and Great Britain are very similar. The Netherlands is a very feminine society compared to the others, and power distance is largest in the USA, which is also the most individualistic country. Uncertainty avoidance and power distance is higher in other parts of Europe, for instance in Greece, Portugal and Spain, where also individualism is much lower.

The matrix of Table 5 should be combined with the scores for the culturally desired welfare state characteristics, cf. Table 3, when we evaluate the reform proposals of the welfare state. We have done this in the first part of Table 6 below, where we weighted the scores from Table 3 with the observed scores for New Zealand. ${ }^{49}$ For sake of comparison we have also added the average scores for Australia and two more or less extreme countries: the USA and The Netherlands.

Table 5 Scores for cultural characteristics

\begin{tabular}{lcccc}
\hline & $\begin{array}{l}\text { Uncertainty } \\
\text { Avoidance }\end{array}$ & Power Distance & Individualism & Masculinity \\
\hline New Zealand & 49 & 22 & 79 & 58 \\
Australia & 51 & 36 & 90 & 61 \\
Great Britain & 35 & 35 & 89 & 66 \\
The Netherlands & 53 & 38 & 80 & 14 \\
USA & 46 & 40 & 91 & 62 \\
\hline & & & & \\
'Europe' & 62 & 38 & 68 & 47 \\
(stand. dev.) & $(24)$ & $(16)$ & $(16)$ & $(22)$ \\
\hline
\end{tabular}

Source: Hofstede (1980), p. 315.

The first part of Table 6 shows that the variation of the scores over countries is quite small, hence it is in particular the ordering of the countries which is of interest - this is consistent with the ordinal nature of Hofstede's scores. One sees that the ordering of the countries is as one might expect: The USA is on the 'tough' side and the Netherlands on the 'soft' side, Australia and New Zealand are in between. It is remarkable for instance how with respect to extensiveness, generosity and equality the Netherlands' scores are much higher, whereas it scores lower with respect to monitoring. It should also be noticed that New Zealand values both generosity and equality higher than Australia, on the other dimensions of the welfare state both countries have equal scores.

In the second part of Table 6 we have indicated tentative scores for the actual situation of the welfare state in New Zealand. Of course the measurement is very imprecise: from the discussion above of

48 Next to Western Europe, these countries include Australia, Canada, Israel, New Zealand and the United States. The average scores for the 40 countries are 64 (24), 52 (20), 50 (25) and 50(20), respectively.

49 We have assumed that each of the four cultural characteristics, when relevant for a characteristic of the welfare state, has an equal weight. Moreover, consistent with Table 3 we have normalized the scores to the range 1 - 3. For example 'regulation' scores ' 3 ' on uncertainty avoidance and ' 1 ' on both individualism and masculinity. The average score for New Zealand then is calculated as follows: $1+\mathrm{UA}^{*}(3-1)+3+\mathrm{IND} *(1-3)+3+\mathrm{MASC} . *(1-3)$ divided by 3 . 
the characteristics of the welfare state in New Zealand we cannot derive scores in decimal points. However, they should be distinctly below ' 2 ', except for monitoring. When we confront the actual scores on the welfare state with the cultural desirable ones, we can observe the discrepancies between both. In the last column of Table 6 we have indicated the discrepancies qualitatively, to stress the imprecisions and ordinal nature of measurement.

The consistency in the observed discrepancies is remarkable: The welfare state is 'tougher' in all respects than is desirable given the cultural background of New Zealand..$^{50}$ One should realize that this situation may lead to social conflict and break the social consensus that had existed until then. Protest meetings and strikes may be the result, which has a negative effect on the labour relations and labour productivity. For instance we noted above that compared to Australia, New Zealand is somewhat less individualistic and has a smaller power distance. Thus one might expect a larger emphasis on equality in New Zealand - which definitely is not the case after the reforms - and more democracy in labour relations. ${ }^{51}$ It is highly debatable to what extent the Employment Contract Act has achieved this.

Table 6 Culture and type of welfare state

\begin{tabular}{|c|c|c|c|c|c|c|c|}
\hline & \multicolumn{4}{|c|}{ Desired scores } & \multirow{2}{*}{$\begin{array}{l}\text { Actual } \\
\text { New Zealand }\end{array}$} & \multirow{2}{*}{$\begin{array}{l}\text { Discrepancy } \\
\text { New Zealand }\end{array}$} & \multirow{2}{*}{$\begin{array}{l}\text { Qualita- } \\
\text { tive } \\
\text { Indicato }\end{array}$} \\
\hline & USA & Australia & New Zealand & the Netherlands & & & \\
\hline $\begin{array}{l}1 \text { Stabilization } \\
\text { policy }\end{array}$ & 1,9 & 2,0 & 2,0 & 2,1 & 1,0 & $-1,0$ & -- \\
\hline $\begin{array}{l}2 \text { Income } \\
\text { policies }\end{array}$ & 1,9 & 2,0 & 2,0 & 2,1 & 1,0 & $-1,0$ & -- \\
\hline $\begin{array}{l}3 \text { Collective } \\
\text { bargaining }\end{array}$ & 1,6 & 1,6 & 1,7 & 1,7 & 1,0 & $-0,7$ & - \\
\hline 4 Regulation & 1,6 & 1,7 & 1,7 & 2,1 & 1,0 & $-0,7$ & - \\
\hline 5 Extensiveness & 1,8 & 1,9 & 1,9 & 2,4 & 1,0 & $-0,9$ & - \\
\hline 6 Generosity & 2,0 & 2,0 & 2,2 & 2,5 & 1,0 & $-1,2$ & -- \\
\hline 7 Equality & 2,0 & 2,0 & 2,2 & 2,5 & 1,0 & $-1,2$ & -- \\
\hline 8 Monitoring & 1,8 & 1,8 & 1,8 & 1,6 & 2,0 & 0,2 & + \\
\hline
\end{tabular}

Scores: 1 - disagree, low; 2 - middle position; 3 - agree, high.

On the micro level some reform proposals can induce negative behaviourial effects. If, as is the case in the United States, not all people have a health care insurance, or if the quality of the basic schools is rather low, then one can expect a negative effect on the country's human capital. ${ }^{52}$ If the benefits are made less generous, income inequality will be rising, making participation of important parts of the population

50 Although we have not really analysed this, casual observation shows that Australia has a much more active stabilization and incomes policy, collective bargaining and a higher incomes equality. Hence the discrepancies with the prevailing culture will be much lower.

51 In the pre-war period corporate structures were also meant to discipline the working class. This view fits collectivism more than liberalism. However, after WWII the trend was towards more democratically organized 'corporatist' structures.

52 In this context it is interesting to observe that the most recent Survey of the OECD for New Zealand (OECD, 1994Z) devotes a special chapter to the human capital problem. 
more difficult. If increasing inequality is contrary to the dominating values of a country - as is the case in New Zealand - the lower ranked people may become frustrated and follow private strategies that influence labour productivity negatively (a negative social efficiency wage effect). A typical example is the increased unrest amongst the Maori population.

\subsection{The political situation}

When we look at the political situation, it is evident that a clear majority can enhance the efficiency of a reform policy. In this respect the fluctuating behaviour of the New Zealand electorate is interesting - cf. Figure 7. The election of the Labour Party in 1984 led to a start of the economic reforms, and Labour was re-elected in 1987. However, the electorate then changed to the National Party in 1990 and the party remained in power in 1993. But the margin for the National Party was very narrow and the 'winner' could only be established after careful counting of the votes. ${ }^{53}$ All the time the reform policy remained on a rather stable track, with increasingly more libertarian features. A typical example of the latter is the Employment Contract Act, which was introduced after the social democratic Labour Party was replaced by the liberal democratic National Party in 1990. Hence and Vranken (1991, p. 490) argue that the Act differs from the North American practice in that it does not provide protection against 'unfair labour practices'. Actually they criticize its 'excessive stress on the need for individual freedom of choice' (p. 491). In terms of section 3.4 the introduction of the Act can be interpreted as a shift from the social democratic point of view to a libertarian one. This can also be seen when one compares the scores on the performance of the welfare state in Table 6 with the policy scores in Table 4.

One should realize that the strongly fluctuating voters behaviour can be interpreted in more than one way. ${ }^{54}$ On the one hand it can be seen as an expression of support for the reform policy. Douglas was popular in 1984 and Rogernomics was on the right track in 1987. However, the Lange government that was elected then got cold feet and slowed down the pace of reforms. Hence National was chosen in 1990 and 1993.

The alternative interpretation is that although there was a widespread belief that policies were necessary, nobody could foresee the extent of changes from Rogernomics and they were definitely not part of the Labour programme in 1984. Labour was re-elected in 1987 due to lack of a credible alternative. In 1990 the share of non-voters increased strongly, ${ }^{55}$ together with votes for other parties. The latter is reflected in Table 7.

\footnotetext{
53 Dutch newspapers presented this election result under the heading: 'Reforms no longer supported by population'.

54 The following discussion is based on Kelsey (1995), Ch. 12.

$55 \quad$ Kelsey (1995), pp. 300-301.
} 
Figure 7 Seats in the parliament in New Zealand, 1960 - 1993

Source: New Zealand Official Yearbook, 1985, 1988-1989, 1994, Department of Statistics, Wellington.

Table 7 also reveals a strong discrepancy between the share of votes and the share of seats: it is very hard for new parties to enter the political arena due to the current First Past the Post (FPP) system. This holds both for the Alliance (Greens, Maoris, Democrats) and for the interventionalist conservative New Zealand First. So the table shows a strong decline in support for the traditional parties that introduced and elaborated the reforms. In its new programme for the 1996 elections Labour wishes to replace the Employments Contracts Act by a ‘fair industrial system’ promoting collective bargaining and legal recognition of the unions. Moreover social welfare benefits would be restored to the level before the 1991 cuts.

Table 7 Election results in 1987, 1990, 1993 and 1996

\begin{tabular}{|c|c|c|c|c|c|c|c|c|}
\hline Party & $\begin{array}{l}1987 \\
\text { seats }\end{array}$ & $\%$ & $\begin{array}{l}1990 \\
\text { seats }\end{array}$ & $\%$ & $\begin{array}{l}1993 \\
\text { seats }\end{array}$ & $\%$ & $\begin{array}{l}1996 \\
\text { seats }\end{array}$ & $\%$ \\
\hline Labour & 58 & 48.0 & 28 & 35.1 & 45 & 34.7 & 37 & 28.3 \\
\hline National & 39 & 44.0 & 68 & 47.8 & 50 & 35.1 & 44 & 34.1 \\
\hline Greens* & 0 & 5.7 & 0 & 6.9 & & & & \\
\hline Alliance** & & & 1 & 5.2 & 2 & 18.2 & 13 & 10.1 \\
\hline NZ First & & & & & 2 & 8.4 & 17 & 13.1 \\
\hline $\mathrm{ACT}$ & & & & & & & 8 & 6.1 \\
\hline
\end{tabular}

* Democrats in 1987; ** New Labour in 1990

Source: Kelsey (1995), Table 12.1. 
It is also indicative for dissent with the existing political climate that after long discussions in a binding referendum in 1993 nearly 54 per cent of the voters opted for a German-style mixed member proportional representation (MMP) system, which is used from 1996 onwards.

One sees from Table 7 that the 1996 elections did lead to substantial changes in the composition of seats in parliament. ${ }^{56}$ The new party in the parliament is the Association of Consumers and Tax payers, founded in 1990 by Roger Douglas following his retirement from parliament. New Zealand First as a powerful position, since neither the combination of Labour and the Alliance nor that of National and the ACT have a majority. In the election campaign New Zealand First carefully has kept distance from both Labour, National and the reform proposals. The current political situation, with no clear majorities is indicative for the lack of consensus in the political field.

However, the extent to which this will lead to changes in the economic and social structure should not be overestimated for two reasons. On the one hand coalition governments will have to be formed and this always makes it hard to introduce strong changes in policy. On the other hand a lot of changes are hard to reverse (for instance the many privatizations), the bureaucracy has worked for over a decade on implementing and enhancing the reforms and finally there are laws like the Fiscal Responsibility Act and the Reserve Bank Act which severely restrict the room for fiscal and monetary policy. ${ }^{57}$

Hence although there is ample evidence of a clear discrepancy between the political view underlying the reforms and the views of the electorate, this will only gradually lead to changes in these reforms.

From our discussion in the last section, we are highly skeptical about the further success of these reforms. The shift away from national consensus and collective bargaining will create a lot of uncertainty, and lead to high transaction costs. Moreover, the position of the low skilled labour force is weakened, which will not only increase the differences in income further, but also lead to a deterioration of their working conditions in general. These elements, together with the libertarian rethoric and views, are inconsistent with the culture of New Zealand as we indicated above, and inconsistent with the social and liberal democratic political traditions. Therefore we expect increasing social unrest and shirking behaviour due to poor motivation, such that productivity increases will remain low. Consensus, which is a necessary ingredient for any successful reform in this respect, is lacking.

\section{Concluding remarks}

In this paper we recognize that reforms of the welfare state can be necessary from an economic point of view. We stress, however, that these reforms also have important social and political dimensions. As a consequence constraints stemming from these latter two dimensions should also be taken into consideration when implementing these reforms. These constraints stem from the insight that the reforms have to be consistent with the culture of a society and its dominant political view. If the reforms do not agree with the culture of a society, this will result in social unrest - for instance wild strikes, protest manifestations and lobbying activities - and shirking behaviour at an individual level. In its turn, this

56 The decline in seats for both Labour and National is stronger than it appears, because the total number of seats increased from 99 in 1993 to 119 in 1996.

57 It is remarkable that an important consideration to introduce the Fiscal Responsibility Act was to enhance the fiscal credibility and investor confidence with the advent of MMP. Kelsey (1995), p. 236. 
implies that the reforms will not meet their goals. Also when the reforms do not fit in with the dominant political view, a further implementation of these reforms will fail - and hence the objectives will not be reached.

One should also realize that consistency with the culture of a society and its dominant political view almost automatically implies that there is consensus about these reforms. We stress that such a consensus is a necessary condition for a successful reform.

We apply the above insights to the reforms in New Zealand. In order to provide some background, we describe the economic situation in New Zealand and compare it with that of Australia since the economic structure of Australia and the external circumstances are rather similar. Moreover, the welfare state in Australia has many characteristics which New Zealand has abandoned deliberately in its reforms.

The comparison between both countries shows the economic situation of New Zealand does not outperform that of Australia. Hence the favourable developments in New Zealand are not necessarily a consequence of the reforms. Moreover, we find that income inequalities have increased sharply in New Zealand and that the lower and middle-class incomes did not increase since 1980.

A closer look at the reforms in New Zealand shows us that they are inconsistent with the culture and the dominant political views of that country. Therefore we expect that a further implementation of the reforms will run into trouble.

Finally, what lessons can we draw from these observations. First, reforms that are of too radical a nature will backfire. The transition costs are very large - cf. the stagnant lower and middle incomes since 1980 in Figure 6. And social dissatisfaction is a real danger - cf. the last election results and the Maori unrest. This holds for reforms that are too radical in the sense that they conflict with the culture of the country. For that reason, a second lesson is that even if the reforms in New Zealand were successful, they cannot automatically be copied to other countries - the Netherlands, for instance, as is proposed by pressure groups in the ministry of economic affairs (Bos, 1994). For one should check whether the reforms are consistent with the culture of that country too. Finally, the introduction of these reforms should be based on consensus. The reasons for introducing these reforms should be explained carefully and discussed widely. Only then success is possible. 


\section{References}

Achterhuis, H., Het Rijk der Schaarste (The world of scarcity), Baarn, 1990.

Barr, N., The economics of the welfare state, London, 1993.

Baar, N. (ed.), Labour Markets and Social Policy in Central and Eastern Europe, Oxford University Press, 1994.

Bardhan, P. and Roemer, J.E., Market Socialism: A Case for Rejuvenation, Journal of Economic Perspectives, 1992, pp. 101 - 116.

Berlin, I., Four Essays on Liberty, Oxford, 1969.

Bray, M. and Haworth, N., Comparing Australia and New Zealand, in : Bray, M. and Haworth, N. (eds.) 1993, pp. 1 - 15.

Bray, M. and Haworth, N. (eds.), Economic Restructuring and Industrial Relations in Australia and New Zealand: A Comparative Analysis, ACIRRT, University of Sydney, 1993.

Bureau of Industry Economics, Trade liberalization and Australian manaufacturing industry, Research Report 29, Canberra, 1989.

Calmfors, L., What Can We Expect from Active Labour Market Policy?, Konjunkturpolitik, 1995, pp. 11 -30 .

Castle, R. and Haworth, N., The Economic Imperative for Restructuring in Australia and New Zealand, in: Bray, M. and Haworth, N. (eds.), 1993, pp. 16 - 38.

Deeks, J., Parker, J., and Ryan, R., Labour and Employment Relations in New Zealand, Auckland, 1994.

Easton, B., Properly Assessing Income Adequacy in New Zealand, New Zealand Economic Papers, 1995, 89 -102.

Esping Andersen, G., The Three Worlds of Welfare Capitalism, Polity Press, 1990.

Etzioni, A., The moral dimension; Towards a new economics, The Free Press, 1988.

Harris, R.I.D. and Daldy, B.M., Labour Market Adjustment in New Zealand, Aldershot, 1995.

Hartog, J. and Teulings, C., Markets, Institutions and Wages, Ministry of Social Affairs, The Hague, 1995.

Hayek, F.A., von, New Studies in Philosophy, Politics, Economics and the History of Ideas, London, 1978.

Henley and Tsakatlotos, Corporatism and the European Labour Market after 1992, British Journal of Industrial Relations, 1992, pp. 567 - 586.

Hince, K. and Harbridge, R., The Employment Contracts Act: An Interim Assesment, NZJIR, 1994,235 255.

Hofstede, G., Culture's Consequences, Sage, 1980.

Jackman, R. and Layard, R., The real effects of tax-based incomes policies, Scandinavian Journal of Economics, 1990, pp. 309 - 324.

Jones, E.L., Culture and its Relationship to Economic Change, Journal of Institutional and Theoretical Economics, 1995.

Kelsey, J., Economic Fundamentalism, London, 1995.

Lindbeck, A., Overshooting, Reform and Retreat of the Welfare State, De Economist, 1994, pp. 1 - 19.

Neubourg, Chr. de, (Ne pas) Agiter avant lémploi, Universitaire Pers Maastricht, 1994.

Putten, J. van, Politieke Stromingen (Political Currents), Utrecht, 1985.

Rankin, K., The New Zealand workforce: 1950-2000, NZJIR, 1993, pp. 214-235. 
Rasmussen, E., Boxall, P., Haworth, N., Hughes, S., Powell, M., Maloney, T., and Wilson, M., Industrial Relations and Labour Market Reforms in New Zealand, University of Auckland, 1995.

Robinson, P., The decline of the Swedish model and the limits to active labour market policy, CEPR Discussion Paper, 259, 1995.

Sen, A.K., On Ethics and Economics, Oxford, 1987.

Sinn, H.W., A Theory of the Welfare State, Scandinavian Journal of Economics, 1995, pp. 495 - 526.

Snower, D., What is the domain of the welfare state?, CEPR Discussion Paper 1018, 1994.

Stark, R., Sociology, Wadsworth, 1994.

Williamson, P., Corporatism in Perspective, Sage, 1989.

Windmuller, J., Collective Bargaining in Industrialised Market Economies, ILO, Geneva, 1963.

Veen, T. van, Cörvers, F, On the measurement of corporatism, Labour, 9, 3 autumn, 1995, pp. 324-442. 